\title{
Critical Factors of Vulnerability That Enable Medina Gounass (Dakar/Senegal) to Adapt against Seasonal Flood Events
}

\author{
Ousmane Diouf Sané1 ${ }^{*}$, Amadou Thierno Gaye², Moussa Diakhaté2, Mawuli Aziadekey³ \\ ${ }^{1}$ Département de Géographie, Université de Lomé, WASCAL, Lomé, Togo \\ 'Laboratoire de Physique de l'Atmosphère et de l'Océan Siméon Fongang (LPAOSF), Université Cheikh Anta \\ Diop, Dakar-Fann, Sénégal \\ ${ }^{3}$ Ecole Supérieure d'Agronomie, Université de Lomé, Lomé, Togo \\ Email: "saneousmanediouf@gmail.com, atgaye@gmail.com,moussa1.diakhate@ucad.edu.sn, \\ guido.aziadek@gmail.com
}

Received 20 June 2016; accepted 31 July 2016; published 3 August 2016

Copyright $@ 2016$ by authors and Scientific Research Publishing Inc.

This work is licensed under the Creative Commons Attribution International License (CC BY).

http://creativecommons.org/licenses/by/4.0/

(c) () Open Access

\begin{abstract}
This paper focuses on people living in Medina Gounass where has been experiencing annually flood events during the rainy season. Besides the climatic conditions, the lack of formal amenity plan has led to the emergence of highly vulnerable urban communities, particularly through informal settlements and inadequate land management. Flood has disrupted their livelihood and caused huge loss of properties. Thus, inhabitants have a long experience of flood events. The study was carried out to assess critical aspects that led Medina Gounass inhabitants vulnerable to flood. Consequently, people in the study area have been practicing various methods at household to mitigate the probable losses. The study found that flood adaptation measures can be made more effective through community initiatives and their participation than at household level which sometimes causes harm in the neighborhood. Structural and non-structural flood management approach seems to be more efficient to alleviate Medina Gounass inhabitants from the flood problems.
\end{abstract}

\section{Keywords}

Factors, Vulnerability, Medina Gounass, Adaptation, Flood

\section{Introduction}

Nowadays, the planet Earth which produces the ecosystem services for human well-being has some disturbances

${ }^{*}$ Corresponding author.

How to cite this paper: Sané, O.D., Gaye, A.T., Diakhaté, M. and Aziadekey, M. (2016) Critical Factors of Vulnerability That Enable Medina Gounass (Dakar/Senegal) to Adapt against Seasonal Flood Events. Journal of Geographic Information System, 8, 457-469. http://dx.doi.org/10.4236/igis.2016.84038 
in a pace that humankind future becomes increasingly a grim reality. Thus, the earth is facing challenges as: raising population, land turning to desert (desertification) and of course climate change.

Climate change in IPCC usage refers to a change in the state of the climate that can be identified (e.g. using statistical tests) by changes in the mean and/or the variability of its properties and that persists for an extended period, typically decades or longer. It refers to any change in climate over time, whether due to natural variability or as a result of human activity. This usage differs from that in the United Nations Framework Convention on Climate Change (UNFCCC), where climate change refers to a change of climate that is attributed directly or indirectly to human activity that alters the composition of the global atmosphere and that is in addition to natural climate variability observed over comparable time periods [1].

The occurrence of disasters linked to damages of physical events and social losses has a direct relationship with the human existence. However, it comes into sight that their frequency and damaging impacts are drastically increased during these last decades. According to [2], the explanation for the continuing increase in losses and their impact on national, regional or local economies can be found not so much in an increase in the number of extreme natural events that occur, but rather in an increase in the number of persons, population density, infrastructure and production located in hazardous areas and in conditions of such vulnerability that they are more susceptible to excessive damage and loss and face considerable difficulties in coping. Furthermore, [3] argued that the severity of the impacts of extreme and non-extreme weather and climate events depends strongly on the level of vulnerability and exposure to these events.

Therefore, flooding can be seen as an unusual presence of water on land to a depth which affects normal activities [4]. Likewise, global population growth, more intensive urbanization in flood prone areas and the limited development of sustainable flood-control strategies, will increase the (potential) impacts of floods [5]. For [6] classification, the distribution of disasters frequency in Africa in 2011 resembled the one seen over the last decade. Hydrological disasters represented $68.8 \%$ of occurrence, followed by climatological (17.2\%) and meteorological disasters (14.1\%).

These statistics are important to highlight because flooding in Medina Gounass seems to be meteorological and hydrological. The link between climate change and human security is now as clear as ever. This changing climate makes many climate scholars to argue that Africa is the most vulnerable continent in the world. As said [7], the poor nations of the world bear the brunt of climate change damages primarily because they are located in the low latitudes and are already too hot.

Then, for [8], Dakar is characterized by an out of control urbanization process. Among the many impacts noted, flooding has appeared recently as a major threat for poor population leaving in the suburbs. Additionally, [9] stated that in extreme cases urban floods can result in disasters that set back urban development by years or even decades. Recent statistics clearly indicate that economic damages caused by urban floods are rising. In 2008 alone, floods affected over 250,000 families and caused extensive damage, with 88 schools and 12 basic health centers under water [10].

Therefore, cities, especially those where urbanization is un-planned or poorly planned, are increasingly vulnerable to hydro-meteorological hazards such as heat waves and floods. Urban areas tend to degrade the environment, fragmenting and isolating ecosystems, compromising their capacity to provide services. The regulating role of ecosystems in buffering hydro-meteorological hazards and reducing urban vulnerability has not received adequate policy attention until now [11].

Changes in some types of extreme events have already been observed, for instance, increases in the frequency and intensity of heavy precipitation events [12]. Rapid urbanization and the growth of megacities, especially in developing countries, have led to the emergence of highly vulnerable urban communities, particularly through informal settlements and inadequate land management [13]. Looking forward to such problems, governmental authorities have put in place adaptive measures. For instance, in 2012, the emergency relief plan (Organization de Secours Aux Catastrophes ORSEC) was activated after the heavy rains of August 26. Due to heavy flooding, 26 deaths, 264,000 people and 7737 damaged houses were reported. In addition, floods displaced over 5000 families (over half from the regions of Dakar and Matam) and contaminated 7700 drinking water sources. With most urban areas of the country affected by flooding, the government of Senegal adopted strong measures, starting with a ten-year program for flood management whose total cost is estimated at more than 700 billion FCFA (US \$1.4 billion) in 2014 [14].

Adaptation is the adjustment in natural or human systems to a new or changing environment. Adaptation to climate change refers to adjustment in natural or human systems in response to actual or expected climatic sti- 
muli or their effects, which moderates harm or exploits beneficial opportunities. Thus, adaptation also presents itself as a continuous property, with levels of adaptive capacity changing over time as the status of vulnerability components identified change and the demands of a shifting risk environment alter the appropriateness of particular asset bundles for risk reduction. In this regards, [15] argues that recognition of the threats to human security associated with climate change has generated growing interest in the relationship between disaster risk reduction and climate change adaptation. It denotes a longer-term and constantly unfolding process of learning, experimentation and change that feeds into vulnerability.

Concerning Dakar, these events are mainly due to a combination of heavy rains and insufficient drainage infrastructures. In the last few years the country has seen recurrent flooding in peri-urban areas of Dakar (Pikine and Guédiawaye areas). This has important economic, social, financial, and environmental impacts. In 2009, US $\$ 82$ million of damages and losses, $12 \mathrm{~km}^{2}$ and 360,000 persons affected [16]. In August 2010, the Government of Senegal decided to prepare an urban development project for rainwater management and climate change adaptation, known as PROGEP, with the support of the World Bank. PROGEP is derived directly from the Post Disaster Needs Assessment action plan, and aims to reduce floods through an integrated and sustainable approach [14]. However, climatic conditions are not the only which trigger flooding in Medina Gounass, socioeconomic factors of the inhabitants are also taken into account. This present study aims to assess climatic factors combine with socioeconomic aspects that exacerbate flood hazard threatening Medina Gounass inhabitants during the rainy season.

\section{Materials and Methods}

The difficulty of the problem we will tackle in this study need a combination of various tools to generate synthetic information related to causes, consequences and flood management (Figure 1).

Medina Gounass is a district located between 14.769 latitude North and -17.387 longitude West in the Guédiawaye department and is totally occupied.

\subsection{Climate Data}

Climate data involved in this study were rainfall amount sorted per decade (per ten days) for the whole time series. These data are from the meteorological agency ANACIM (Agence National de l'Aviation Civile et de la Meteorologie) principally the Dakar Yoff station. The dataset covered the time period of 1947 to 2013.

\section{Sampling Method}

[17] Sampling method is used here to calculate sample size in a table. A 95\% confidence level and P $=5 \%$, 7\% and $10 \%$ are also assumed for different population size by the equation below.

$$
n=\frac{N}{1+N(e)^{2}}
$$

where $n$ is the sample size, $N$ is the population size and $e$ is the level of precision. For this study area for instance, the first investigations give a total population of Medina Gounass to 44.000 inhabitants. Then, according to the formula, the sample will focused on 100 households and the respondent should have at least eighteen years old.

This research adopt also an exploratory approach using predominantly qualitative methods with techniques of interviews and focus groups that allow the research participants to give very detailed and specific answers [18]. Several open interviews are undertaken which are not interviews with questions that cannot just be answered with a yes or a no, but, they are open for discussion free and flexible with stakeholders about floods and there consequences towards people living in the study are and also the disaster managers...

\subsection{Climate Data Analysis}

To determine the temporal variation of the rainfall, a rainfall anomaly index following [19] is used. This index is calculated by the following formula:

$$
X_{j}=\frac{1}{N_{j}} \sum_{i=1}^{N_{j}} \frac{r_{i j}+m_{i}}{\sigma_{i}}
$$




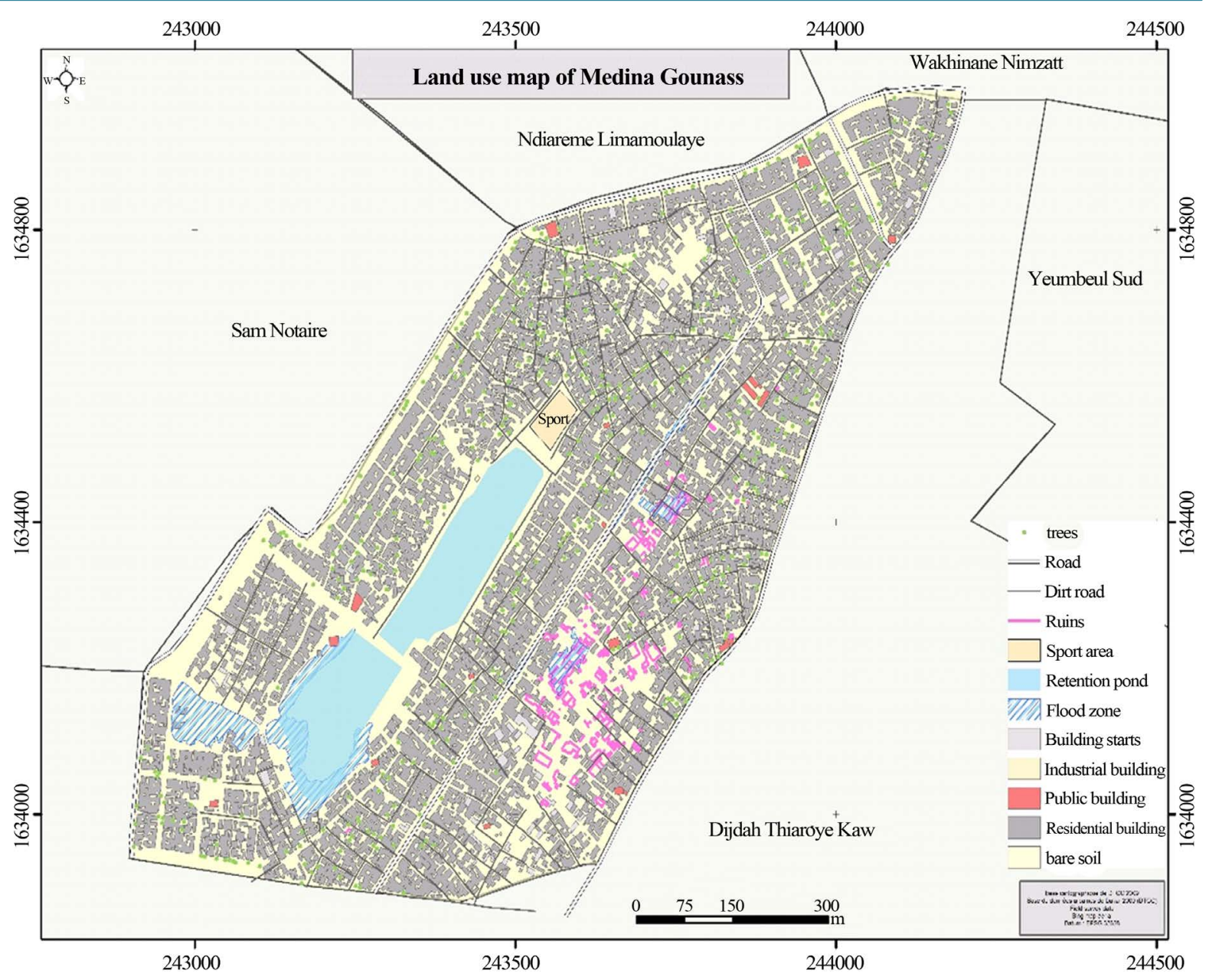

Figure 1. Land use map of Medina Gounass.

where $r_{i j}$ is the rainfall measured in a year $j$ at a station $i, m_{i}$ and $\sigma_{i}$ are the average and standard deviation of the rainfall recorded at the station $i$ and $N_{j}$ is the number of stations that have recorded rainfall in the year $j$. Since, in our study there is one station (Dakar Yoff station), therefore, the above-mentioned formula becomes:

$$
X_{i}=\frac{r_{i}-m}{\sigma}
$$

where $X_{i}$ is the rainfall anomaly index for the year $I, r_{i}$ is the total annual rainfall for the year $i, m$ and $\sigma$ are the average and standard deviation of the annual rainfall recorded during the period of time chosen for this study.

\section{Socio-Economic Data Analysis}

EpiData software, excel and SPSS (Statistical Package for Social Sciences) for the statistical analysis. EpiData Analysis is used for: Basic descriptive Analysis of quantitative data, defining and modifying data, editing/ correcting data already entered.

For use of EpiData software, questions should be coded in quantitative form so that it could be easily analysed. This software is very useful because it can allow us to convert different variables from the field survey to an excel file for the statistical analysis in SPSS. Thus Pie charts and bar graphs are drawn [20].

\section{Results and Discussions}

\subsection{Rainfall}

Figure 2 present Dakar-Yoff station (the nearness one of Medina Gounass) rainfall evolution. The bars 


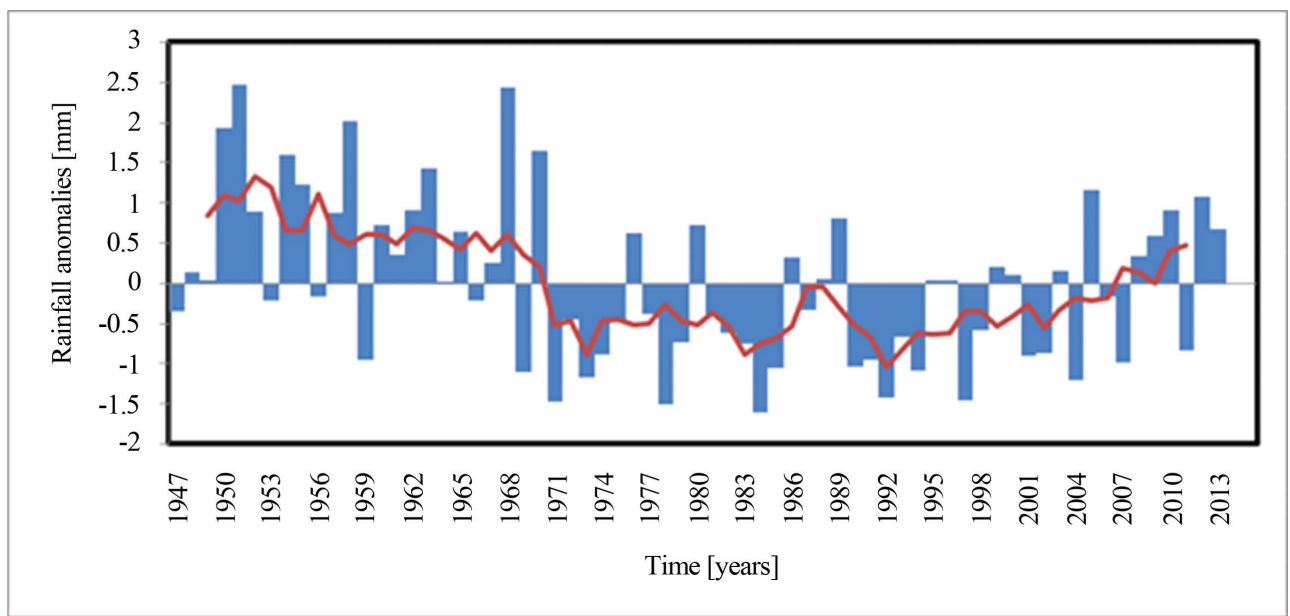

Figure 2. Annual rainfall index variation (Dakar Yoff Station).

correspond to rainfall anomalies computed using Lamb 1982's approach: negatives bars represent deficits years and vice versa. The 5-years mobile mean of these anomalies are represented on red curve in order to appreciate the smoothed evolution of these interannual anomalies. The rainfall evolution is much correlated to that of the Sahel rainfall [21]. One can identify the long Sahel droughts between 1970 and 1999, and the recent recovery since 2000.

In this annual rainfall index, bars correspond to rainfall anomalies computed using Lamb 1983's approach, and 5-years mobile mean of these anomalies are represented on red curve.

Even though the index is used to determine flood and drought years, this study puts emphasis on floods. To justify the relevance of this index, the field survey revealed that 1989 can be considered as a base line concerning the history of floods in the area. Nevertheless, [22] argued that in 2005, $450 \mathrm{~mm}$ of cumulative rainfall recorded in 24 hours in August 2005 caused a damaging flood in Dakar and its suburbs. For us, it's too much to record such a quantity of rainfall in a single day in Dakar. The data we have did not say the same thing even though they are from the same meteorological station of Dakar Yoff. She over estimate this information because in our data, $336 \mathrm{~mm}$ of rainfall are recorded in the whole August 2005.

It is well understood that differences between wet and dry years in such regions are largely determined by sub-seasonal changes in the number of rainfall events, rather than intensity; in other words, rainfall deficits in dry years are primarily the result of fewer large convective systems, mainly in July and August. It has been argued that flood hazards in this part of the world have been largely ignored, despite the seriousness of the problem. At the beginning of the new millennium, more and more extreme wet events and associated damage have been recorded, with the most notable occurrences in 2002, 2003, 2005, 2006, and 2007 [23].

A close observation of the annual rainfall index graph, suggests that there are wet years during the period 1947-1970 and 1970 to 1999 corresponds to a long period of dryness. This period corresponds to the long droughts which hit the Sahel in general. In 1989, there was a wet year and after that we fall again in drier years till the early 2000s where wet years seem to be more frequent. In this last decade even further, rainfall is not without negative consequences for urban inhabitants [24] [25]. Hence, Dakar suburban’s particularly those from Medina Gounass, are constantly on rain water mixed with sewage, and drainage water which obstruct people's activities [20] [26]. This particular aspect is emphasized by [22] saying that in August and September 2005, around 200,000 people in poor suburbs of Dakar had their feet in the water and were later displaced and resettled in precarious sanitary conditions. As a result, it becomes a threat for human security generally.

This graph below is an illustration on what people's memory remembered about the past. In this regard, the question asked is to remember the first flood event they have experienced. The statistics showed that the year 1989 is by far the most represented. We don't tell that it is the only one but the memory of people we addressed is limited to that event (Figure 3).

The survey revealed that $47 \%$ of people point out that more than 25 years which correspond to 1989 and when we look at the annual rainfall index, it's obvious that it was a wet year. The explanation is that people have passed a long period of dryness during the 1970s drought period. There is a retreat of the water table and the 


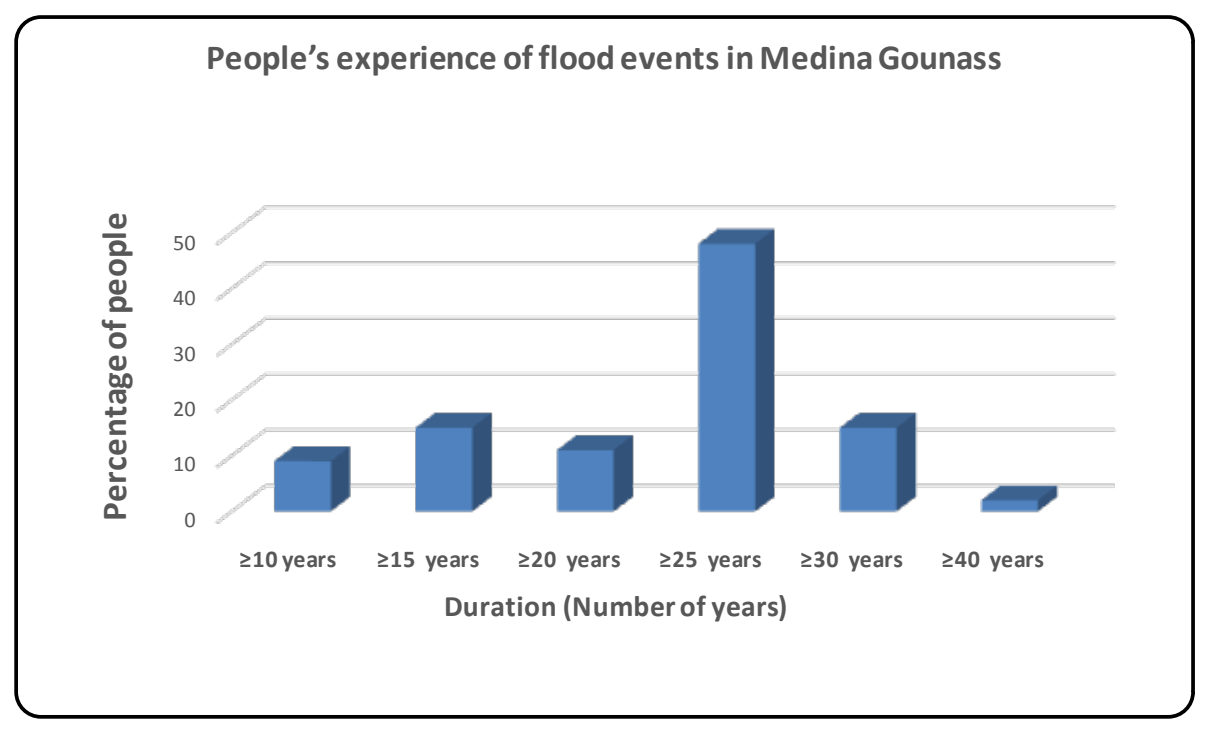

Figure 3. Experience of flood events.

demographic growth. At the same time, rural people came in the capital city to find new job opportunities. The best area to them for settlement is the suburbs where land is cheaper.

Since the 1970s drought years, people have lost prevention measures, and live haphazardly without any amenity plan neither sewage and drainage system. As a result, when a normal event of rainfall comes they are flooded and it's a psychological shock. The normal, by referring to the period given by World Meteorological Organization is the period of (1961-1990) in which the normal is $424.046 \mathrm{~mm}$ within the time series we have. Thus, 1989 can be considered as normal toward precedent years with a total of $458.5 \mathrm{~mm}$. People's activities are determine by the behaviors of the climate.

After 1989s event, the index showed that we fall again in years of dryness event wet years can be noticed before the return period in 2005. If the duration before another important rainfall event occurs, people tend to forget about adaptation measures. Though their vulnerability to floods increases. That's why when the total rainfall is $659.5 \mathrm{~mm}$ in 2005 it is too much in area already flood prone. Since that period, every years the area experience flooding as it is seen in the index.

However, we cannot say with certainty that it's a return period for more rainfall in coming years. What is known with the predictions of the IPCC is that we are in climate change and people will experience more extreme events as droughts and floods and African countries will suffer most because located in low latitudes. These changes in the local climate cannot solely explain the social vulnerability of Medina Gounass suburban's. Other explanations can be found in the socioeconomic characteristics.

\subsection{Socioeconomic Characteristics}

A questionnaire on one hundred household randomly selected is administrated within the study area. These people have the opportunity to respond to the questionnaire related to a certain number of social, economic, educational, environmental, and existential.

\subsubsection{Sex Ratio per Age of the Sample}

The study conducted in Medina Gounass district shows that the percentage of males who respond to the questionnaire is $81 \%$ and $19 \%$ for females. It can be explain by the fact that in this area, males have the power and the responsibility to be the one who lead the household.

For instance, during the field survey, we have cases where ladies did not want to answer the questionnaire because their husband were absent. There are cultural believes that the lead of a household is a male as it is the case in Medina Gounass. This assumption appears clearly during the focus group when female refused to talk first before males. Thus, they did not want to argue differently regarding males viewpoints.

This observation is reinforce by the fact that we are in an area deeply rooted in traditions and reflect a com- 
munity majorly composed by Muslims which fundamental characteristics is that the male is the chief of the family. This affirmation can be highlighted by the predominance mosques and we did not have any church in this area.

In addition, historically, Medina Gounass is created in 1960, and its name symbolizes a recognition of first inhabitants disciples of the religious guide El Hadji Mamadou Seydou Ba (great scholar of Haalpulaar community founder of Medina Gounass Tambacounda) whose intervention was determinant to threats from eviction that have long hung over the neighborhood. The naming ceremony took place in His presence in this neighborhood located opposite what is now the current police station of Guédiawaye [27].

This aspect highlight the link between religion and political leaders which sometimes can be a real obstacle for the socio-economic development of the nation. Most of the time religious guides put pressure on the government to have some facilities even though in the long run become problematic for inhabitants particularly and the State in general. It is the case in what happens in Medina Gounass. The former government let people live haphazardly in a low lying area. Consequently, people are vulnerable to flood and have their houses flooded because of the pressure they put on land and lack of amenity plan in that place.

Additionally, the only sex ratio cannot solely explain social vulnerability of people living within this area. Another explanation can be found in the composition by age (Figure 4).

In this graph, we see that the average age of the sample is 47 years for males and 39 years for females. These statistics show that in this area the population is relatively young. Consequently, they are supposed to be more resilient than elders against flood events which are recurrent. In an interview with an old man in the study area, the question of the place of young people against flooding was asked and it seems that they not really involved.

In my view, education have an important place, but employment is not an isolated factor for young people's involvement in flood management.

Thus, this categories revealed by this present study can be considered sociologically speaking as full adulthood when the preoccupations of people are much turn on patterns of career progression and termination.

\subsubsection{Employment Rate}

Concerning the employment rate, the survey revealed that we have $52 \%$ of males and $8 \%$ of females are employed. Contrarily, we have a rate of unemployment of $29 \%$ for males and $10 \%$ for females (Figure 5).

These statistics showed an employment rate of Medina Gounass males above the average. That means people are employed but the real question is that which kind of job they are doing and how much they are paid. For instance, the large majority is not employed by the State as civil servants but by some enterprises, particular persons. Some of them run their own small business like traders. Socio-economic sectors are sensitive and vulnerable to climate change and variability. When there is an extreme like floods in the study area, all people activities

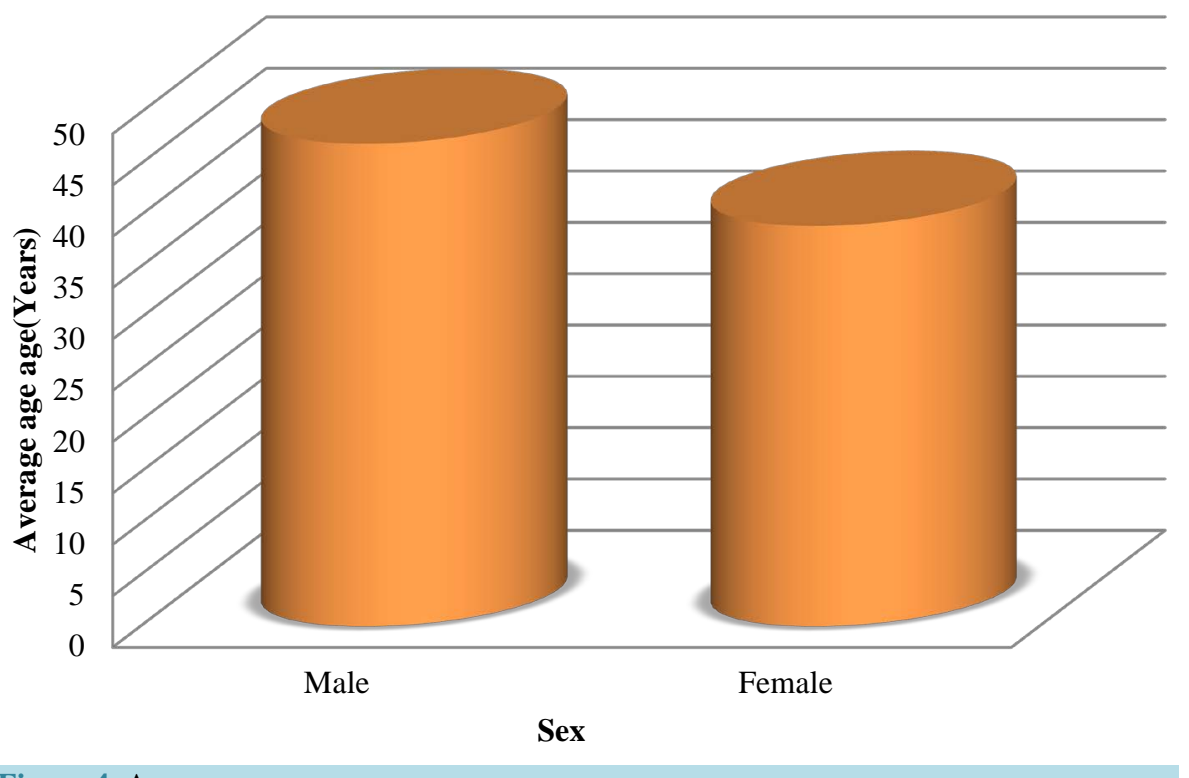

Figure 4. Average age. 


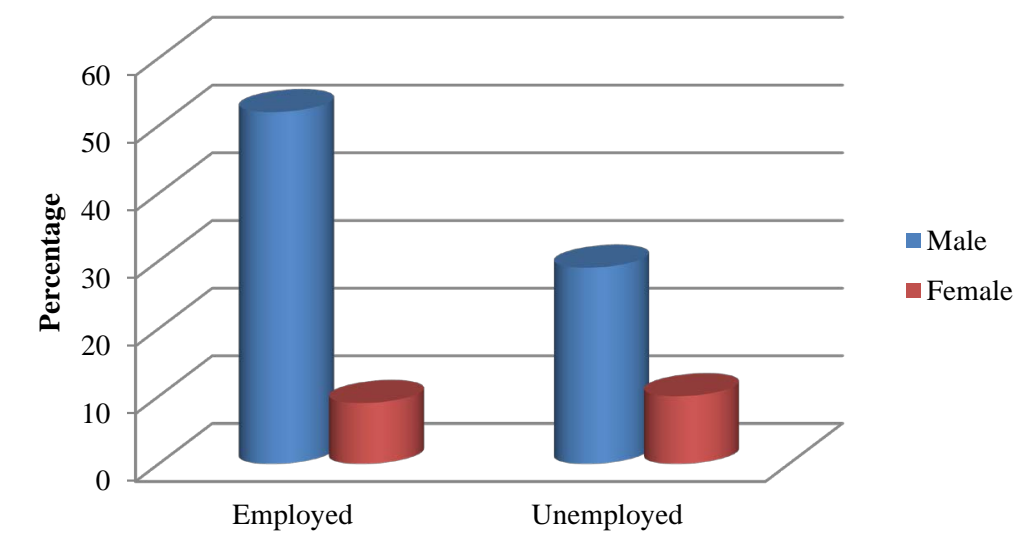

Figure 5. Employment rate.

are disrupted. Climate change increases flood intensity and thus exacerbates public and private property damages. Problems with floods and flooding are strongly related to population, population density and standard of living, especially in the developing countries [28].

These statistics did not show much how the inhabitants are economically vulnerable.

The socio-economic activities in the site are mostly dominated by small businesses reduced into informal trade on public roads, the weekly market and others occupations such as hairdressers, carpenters, tailors...

Furthermore, the first inhabitants of Medina Gounass came from the rural area (haalpulaar ethnic group coming from Eastern Senegal were the majority with a small minority of Serere) and mostly illiterate. For many years, the lack of a school in the locality excluded children from school [29].

These statistics revealed that there is $89 \%$ use their on tap, $2 \%$ use the fellow's and $9 \%$ are obliged to use the public taps. Medina Gounass do not have a major problem of fresh water supply. There is a relatively good distribution of drinking water. It also has public located around the area. However, people tend to use wells and pumps, especially in case of shortage to refuel themselves with all the diarrheal diseases that can be caused.

Additionally, to have access to the tarred road it's took about eight minutes. Eight minutes are enough for a human being to die if there is no roads in that area for the mobility. The area lacks of roads; there only track for inhabitants to move. That's why in the case of flood events rescue teams find difficulties to access certain zones within the study area.

Furthermore, the average time people lose to go to the market is much greater. The explanation is that, the area lacks of a permanent market. There is only one weekly and people have to move to the neighbouring areas to do their shopping. This is another type of vulnerability Medina Gounass inhabitants have to face in their everyday life. The access of the basic need for a good life are absent in this area. These aspects highlighted above can be sustain by the lack of sewage in Medina Gounass.

\subsubsection{Utilization of Sewage and Septic Tank}

The survey revealed that the wash rooms in the study area are not connected to the sewage. For that, only $8 \%$ are connected and $92 \%$ use the septic tanks. It is a real problem in this area because they are subject to recurrent flood events and the water table is not deeper.

When flooding occurs, the septic tanks water and rain water flow together and affect populations. The only one who are connected to the sewage system are located near the main road colled Taly Boubess prolonged passing to the municipality house. Thus, Sanitation and wastewater management is one of the major environmental problems facing Guédiawaye department and Medina Gounass particularly [27].

Additionally, [22] in 2009 highlighted in her Master thesis that, the implementation of the district of Medina Gounass in an area of bowl in heart Niayes of Pikine explains the observed permanent flooding since 2005 (but already present since 1989). As a result, the clay soil, the character flush of the water table, lack of sanitation infrastructures and limited means of the district amplify the problems of populations exposed to health and environmental risks. This fact is also an argument of eight persons during the focus group with some of Medina Gounass inhabitants.

For the local government, it is costly to afford necessary equipment though this situation impacts negative on 
the public health and the life quality of populations resulting from the absence or inadequate sanitation by the same time becomes a threat for human health security. Additionally, in the district most houses have devices or materials to evacuate feaces. Challenges remain in the areas where the water table is not deep. In these areas, inhabitants repeatedly dig holes in their concessions or outside near their doors where they pour liquid waste coming from septic tank. In the rainy season with the flood events, it becomes difficult to breath with bad smell. This situation is exacerbated by the lack of sewage and drainage network.

\subsubsection{State Assistance}

The survey results highlight that $58 \%$ of people argue that having the assistance of public authorities and $42 \%$ say that they are not assisted by the State. For most of the time it is a political issue for solving the problem.

This is the game of politicians when a disaster occurs the all try to have the empathy of those affected. At the end of the day, nothing much happens. This attitude is highlighted by one inhabitant in an interview saying that, the victims of Gounass are formal. They would rather need support on the rapid drainage system than these gifts politicians used to bring for them like bags of rice. He added that they are not starving of hunger and the President Macky Sall collaborators are doing the same things as the former President Wade did. They prefer power driven pumps or health assistance because sewage water are mixed to rainwater in which theirs children are exposed all the time, rather than those gifts which are dividing people within the area. Additionally, the Major Deputy of the former regime argues that Ministers of the former regime have done more and better. During the last rainy season, despite the work done by the former regime, there is no resettlements no shelters.

On the field, we have seen some achievements like basins (illustrated below) done by the government and his partners (Picture 1, Picture 2).

This achievement is a governmental response against flooding and in these basins are fresh water ecosystems where people living in the vicinity go fishing. Then, adaptation can be felt acting to shape all aspects of vulnerability and is observable through the systems and outcomes of learning planned and spontaneous, pre- and post-disaster [30]. As is it highlighted above, adaptation is a continuous process which encompasses also taking advantage of opportunities from a disastrous event to rebuild sustainable infrastructures and enhance people resilience [13].

In this situation, it depends on which political side you are and as researcher we have to be more careful in the interpretation. The fact is that our field data show the involvement of the government in flood management. As a result, the interview with the former Mayor Deputy Cheikh Dieye highlighted that the present government has created and additional site in a location called Tivaouane Peul named Plan Tawfekh, were some of Medina Gounass dwellers will be relocated. There are also other projects in collaboration with the local government for Medina Gounass to become a modern city with all the infrastructures needed. For those projects to become a reality, many people have to move from the area. We can consider these different viewpoints as an answer to the hypothesis that the public actions against flooding were not preventive but took effect after damage, following

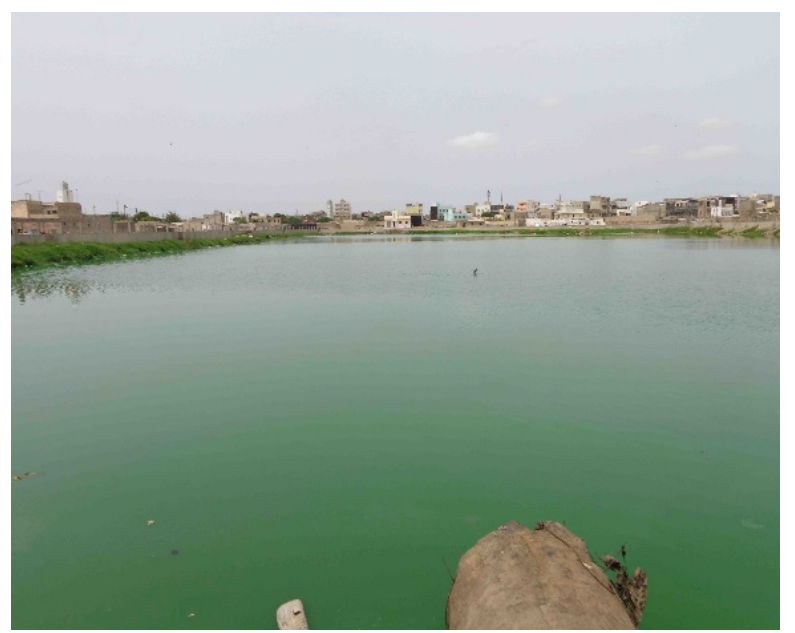

Picture 1. Basin 1 in Med. Gounass for flood reduction. Field survey, July 2014. 


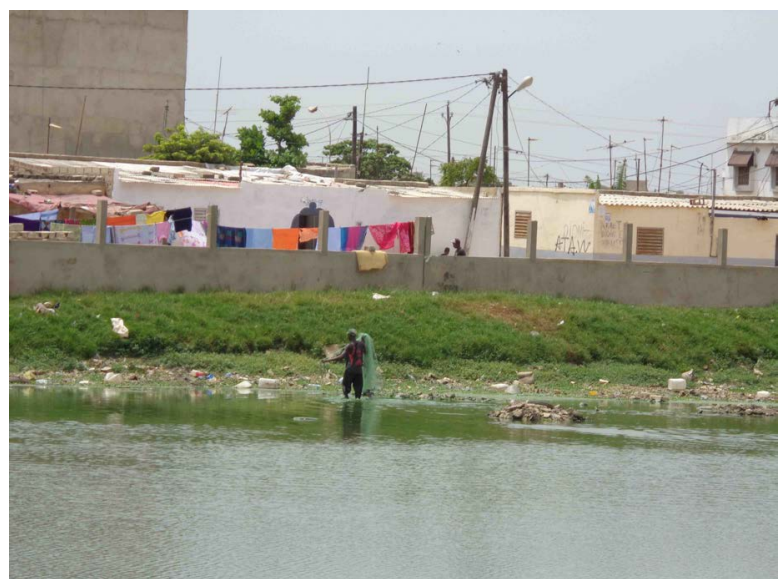

Picture 2. Basin 2 in Med. Gounass. Field survey, July 2014.

social contestations and made floods the focus of media attention. Public actions should be preventive and not waiting till the drama occurs to act. This is the major problem we have in our country, political leaders did not have the incentives to put in place preventive measures against flood disasters. There are many similar dramatic cases which happened in Senegal this last decade because of the leniency of political leaders.

Furthermore, the focus group gave us more information about governance. One of the participant argued that the deceased Mayor of Guédiawaye Macky Sall in the 1990 after the first huge flood event in 1989 took some measure for the restructuration of Medina Gounass. This plan had three phases in which the first was people displacement and dig canalisations to channel runoff water through the ocean. However, this plan lacks of support measures because in Medina Gounass, houses are made in cement and those who have to give up their houses should benefit houses with the same number of rooms as it was the case in there former site. At that time four hundred (400) households were selected to join the site but the municipality did not have enough money for that. The cost of the project was estimated to seven billion in CFA currency $(7,000,000,000 \mathrm{f} \mathrm{cfa})$ which correspond to more than twelve millions of US dollars 12,700,000 \$US.

Unfortunately, President Wade's government forgot about restructuration and talk about "Plan Jaxaay" which delocalized some people to allow their tractors and engines which have to dig the basins to move inside the area. Then, the advantage of this project is that, it collect runoff water into the basins and reduce floods. But, the major disadvantage lies in the fact that, families are scattered because the houses in the relocation site are too small to contain big families as it was the case in Medina Gounass. This relocation do not take in account the social side.

\subsubsection{Willingness to Leave the Area and Adaptation Measures}

The study shows that there are $48 \%$ of them want to leave the place and $52 \%$ to stay. The question depends on the motivation of each of them. For instance, those who want to leave the area are motivated by the fact that they were not in security living almost a decade in such situations. For that they claim willing a better future for their children (Figure 6).

Even though the place is a risky area, the major part of them did not want to leave. The main reason is that they have a particular relationship with the place they have been living for decades. This view lead us to think about a social capital they gain in this area during these long years of interactions between all the members of the community.

The volume of social capital possessed by a particular agent depends on the extent of the network of connections he can effectively mobilize and the volume of the (economic, cultural or symbolic) capital gained by his own within each of those to whom he is related. Social capital is defined as a complex social relationship that an individual have with his immediate environment which fit into the macro network of a community [31]. For those who want to leave the place, the major problem is that they do not have enough financial resources to do so even though it remains space in a big city where amenities already exist but, they cannot afford it.

For the adaptation measures people multiple strategies are used to deal with floods. Therefore, power driven pumps are the most commonly used and these means are provided by the government to help inhabitant cope 


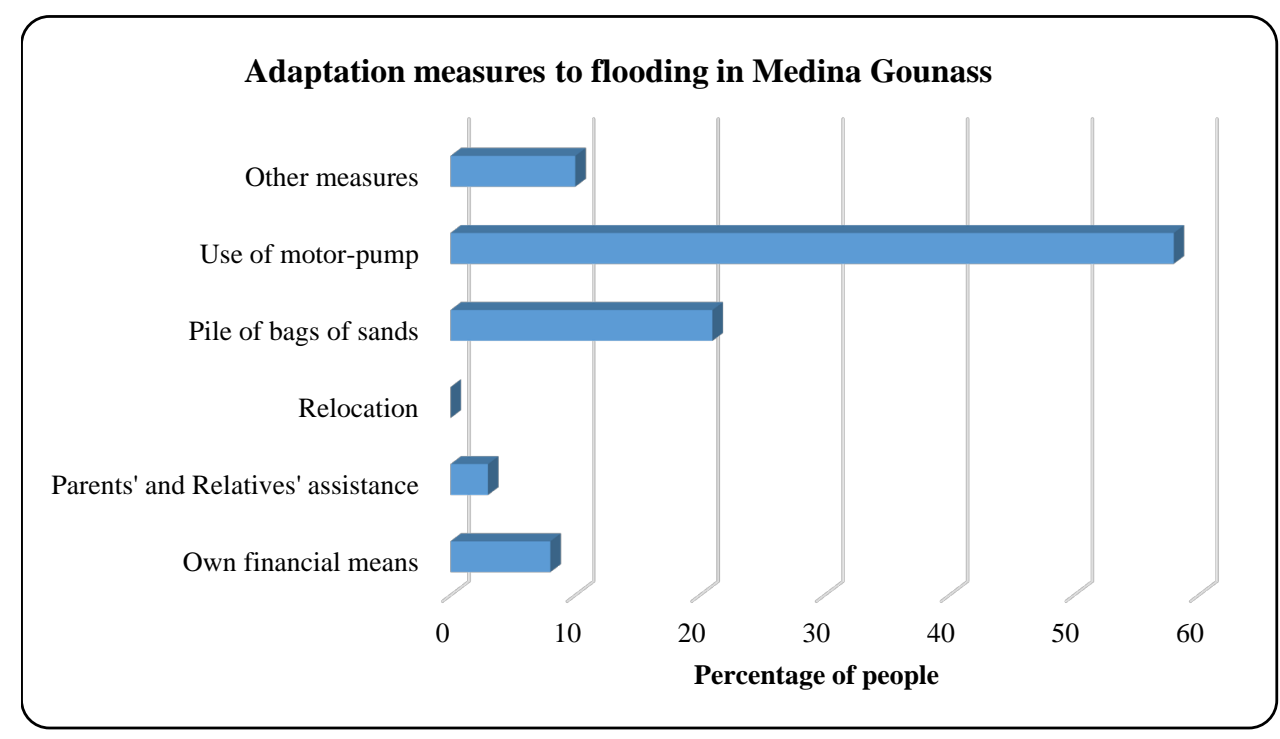

Figure 6. Adaptation measures Medina Gounass inhabitants put in place to face flood events.

with recurrent floods events. For that, following the floods of August 2012, the Government of Senegal was committed to significantly strengthen its post-flood recovery policy. The strong political commitment and key actions that enabled the Government to launch the Ten-Year Flood Management Program [14]. It is good to see this kind of actions but at household level these actions cannot be seen because poverty is endemic in that area. It has known that floods can be caused by anthropogenic activities and human interventions in the natural processes such as increase in settlement areas, population growth and economic assets over low lying plains prone to flooding leading to alterations in the natural drainage [32]. Additionally, others put pile of bags of sand near their houses as a coping strategy to prevent runoff water enter in their properties. This fact generates sometimes violent conflicts between neighbors. Therefore, studies on, the social production of vulnerability as a central theme of research on the human dimensions of environmental change hold that vulnerability to environmental disasters is largely a product of the way humans occupy and use the natural environment [33].

As a result, we can say that in Medina Gounass, structured and non-structured adaptations means are used by government in one hand by local communities in another hand. All these aspect highlighted above are to take into account in assessing social vulnerability.

\section{Conclusions}

In sum, we can say that Medina Gounass has a long history of flood hazards. The climate data showed that after the periods of 1970s droughts, the area experienced different waves of settlement and people at that time did not care about what will happen if there is return period to more rainfall. This view leads us to think about a social capital they gain in this area during these long years of interactions between all the members of the community. For those who want to go, the major problem is that they did not have enough financial resources to do so even though there are areas in a big city where amenities already exist but, they cannot afford it.

Another aspect concerning the social vulnerability in Medina Gounass is related to the connection to the drainage system. The survey revealed that the wash rooms in the study area are not connected to the sewage. It is a real problem in this area because they are subject to recurrent flood events and the water table is not deeper. It constitutes the hygienic problem and a factor of vulnerability towards water borne diseases and water related diseases.

Medina Gounass inhabitants are not resilient. The survey and the focus group done showed that to fight against floods, people use the bags of sand and power driven pumps. These measures are not sustainable because they lack of perspective for the future. These power driven pumps are provided by the government and spend money for fuelling and monitoring in the periods flood events instead of putting in place sustainable adaptation measures as putting in place sustainable infrastructures which can channel to runoff waters to the ocean during the rainy season. Therefore, to assess Medina Gounass vulnerability to floods, climate is not a stand-alone cause 
but socioeconomic factors are by far the most critical.

\section{Acknowledgements}

We would like to thank the German Federal Ministry of Education and Research (BMBF), WASCAL (West African Science Service Center on Climate Change and Adapted Land Use) Project, coordinated by the Center for Development Research (ZEF, Bonn University), Université de Lomé/Togo, meteorological agency ANACIM principally the Dakar Yoff meteorological station, to Professor Kokou Kouami, Boubacar Sané (Kéba), Mamadou Lamine Diop.

\section{References}

[1] IPCC (2007) Climate Change 2007: Impacts, Adaptation and Vulnerability. Synthesis Report. Contribution of Working Group II to the Fourth Assessment Report of the Intergovernmental Panel on Climate Change. Cambridge University Press, Cambridge.

[2] Lavell, A., Mansilla, E. and Smith, D. (2003) Local Level Risk Management: Ideas and Notions Relating to Concept and Practice. Regional Programme for Risk Management in Central America CEPREDENAC-PNUD.

[3] Cardona, O.D., van Aalst, M.K., Birkmann, J., Fordham, M., McGregor, G., Perez, R., Pulwarty, R.S., Schipper, E.L.F. and Sinh, B.T. (2012) Determinants of Risk: Exposure and Vulnerability in Managing the Risks of Extreme Events and Disasters to Advance Climate Change Adaptation. In: Field, C.B., Barros, V., Stocker, T.F., Qin, D., Dokken, D.J., Ebi, K.L., Mastrandrea, M.D., Mach, K.J., Plattner, G.-K., Allen, S.K., Tignor, M. and Midgley, P.M., Eds., A Special Report of Working Groups I and II of the Intergovernmental Panel on Climate Change (IPCC), Cambridge University Press, Cambridge, UK, and New York, 65-108.

[4] Clement, A.R. (2013) An Application of Geographic Information System in Mapping Flood Risk Zones in a North Central City in Nigeria. African Journal of Environmental Science and Technology, 7, 365-371. http://dx.doi.org/10.5897/AJEST12.182

[5] Jonkman, S.N. (2005) Global Perspectives on Loss of Human Life Caused by Floods. Natural Hazards, 34, 151-175. http://dx.doi.org/10.1007/s11069-004-8891-3

[6] Guha-Sapir, D., Vos, F., Below, R. and Sylvain, P. (2011) Annual Disaster Statistical Review 2011. Centre for Research on the Epidemiology of Disasters (CRED), Institute of Health and Society (IRSS), Université Catholique de Louvain-Brussels, Belgium.

[7] Mendelsohn, R., Ariel Dinar, A. and Williams, L. (2006) The Distributional Impact of Climate Change on Rich and Poor Countries. Environment and Development Economics, 11, 159-178. http://dx.doi.org/10.1017/S1355770X05002755

[8] Mbow, C., Diop, A., Diaw, A.T. and Niang, C.I. (2008) Urban Sprawl Development and Flooding at Yeumbeul Suburb (Dakar-Senegal). African Journal of Environmental Science and Technology, 2, 75-88.

[9] World Meteorological Organization (WMO) (2008) Urban Flood Risk Management, Associated Programme on Flood Management, Technical Document No. 11, Flood Management Tools Series.

[10] Global Facility for Disaster Reduction and Recovery (GFDRR) (2011) Vulnerability, Risk Reduction, and Adaptation to Climate Change. Report, Senegal.

[11] Depietri, Y., Renaud, F.G. and Kallis, G. (2012) Heat Waves and Floods in Urban Areas: A Policy-Oriented Review of Ecosystem Services. Sustainability Science, 7, 95-107. http://dx.doi.org/10.1007/s11625-011-0142-4

[12] UNFCCC (United Nations Framework Convention on Climate Change) (2007) Climate Change: Impacts, Vulnerabilities and Adaptation in Developing Countries. Climate Change Secretariat (UNFCCC), Bonn.

[13] IPCC (2012) Summary for Policymakers. In: Field, C.B., Barros, V., Stocker, T.F., Qin, D., Dokken, D.J., Ebi, K.L., Mastrandrea, M.D., Mach, K.J., Plattner, G.-K., Allen, S.K., Tignor, M. and Midgley, P.M., Eds., Managing the Risks of Extreme Events and Disasters to Advance Climate Change Adaptation, A Special Report of Working Groups I and II of the Intergovernmental Panel on Climate Change, Cambridge University Press, Cambridge, UK, and New York, $1-19$.

[14] Global Facility for Disaster Reduction and Recovery (GFDRR) (2014) Senegal: Urban Floods Recovery and Reconstruction since 2009: Recovery Framework Case Study, Senegal.

[15] O’Brien, K., et al. (2008) Disaster Risk Reduction, Climate Change Adaptation and Human Security. Report Prepared for the Royal Norwegian Ministry of Foreign Affairs by the Global Environmental Change and Human Security (GECHS) Project, GECHS Report 2008, 3.

[16] Projet de Gestion des Eaux Pluviales (PROGEP) (2011) Senegal Storm Water Management and Climate Change 
Adaptation Project. Development Impact Evaluation Initiative, Naivasha.

[17] Israel, G.D. (2013) Determining Sample Size. Institute of Food and Agricultural Sciences (IFAS), University of Florida, PEOD-6, 1-5.

[18] Vanderstoep, S.W. and Johnston, D.D. (2009) Research Methods for Everyday Life Blending Qualitative and Quantitative Approaches. Jossey-Bass, San Francisco.

[19] Lamb, P.J. (1983) Short Communication Sub-Saharan Rainfall Update for 1982: Continued Drought. International Journal of Climatology, 3, 419-422. http://dx.doi.org/10.1002/joc.3370030410

[20] Sané, O.D., Gaye, A.T., Diakhaté, M. and Aziadekey, M. (2015) Social Vulnerability Assessment to Flood in Medina Gounass Dakar. Journal of Geographic Information System, 7, 415-429. http://dx.doi.org/10.4236/jgis.2015.74033

[21] Janicot, S., Mounier, F., Hall, N., Leroux, S., Sultan, B., et al. (2009) Dynamics of the West African Monsoon. Part IV: Analysis of 25 - 90 Day Variability of Convection and the Role of the Indian Monsoon. Journal of Climate, 22, 15411565.

[22] Priem, M. (2009) L’Efficience des Plans et Programmes d’Aménagement dans la Lutte contre les Inondations à Dakar: Zoom sur le Quartier de Medina Gounass. Mémoire de Master en Sciences et Gestion de l’Environnement, Université Libre de Bruxelles, Brussel.

[23] Tchotsoua, M., Fotsing, J.-M. and Moussa, A. (2007) Evaluation des Risques d’Inondation dans la vallée de la Bénoué en Aval du Barrage de Lagdo (Cameroun). Actes des JSIRAUF, Hanoi, 1-9.

[24] Diop, C. and Sagna, P. (2011) Vulnérabilité Climatique des Quartiers de Dakar au Sénégal: Exemples de Nord-FoireAzur et de Hann-Maristes. Renforcer la Résilience au Changement Climatique des Villes: Du Diagnostic Spatialisé aux Mesures d'Adaptation, Université Paul Verlaine, Metz.

[25] Wade, S., Faye, S., Dieng, M., Kaba, M. and Kane, N.R. (2009) Télédétection des Catastrophes d’Inondation urbaine: Le Cas de la Région de Dakar (Sénégal). Journées d’Animation Scientifique (JAS) de l’AUF, Alger, 1-7.

[26] Sene, S. and Ozer, P. (2002) Évolution Pluviométrique et Relation Inondations-Événements Pluvieux au Sénégal. Bulletin de la Société Géographique de Liège, 42, 27-33.

[27] Djigo, A.A. (2005) Population et Environnement: Assainissement des Eaux Usées et son Impact sur la Situation Socio Sanitaire des Populations de Medina Gounass. Mémoire en Population Développement et Santé de la Reproduction.

[28] Devkota, R.P., Cockfield, G. and Maraseni, T.N. (2014) Perceived Community-Based Flood Adaptation Strategies under Climate Change in Nepal. International Journal of Global Warming (IJGW), 6, 113-124. http://dx.doi.org/10.1504/IJGW.2014.058758

[29] Sarr, C. (2010) Stratégie du Plan Jaxaay pour la Gestion des Inondations et la Recomposition des Zones Inondées dans la Banlieue Dakaroise: Cas de la Commune d’Arrondissement de Médina Gounass. Faculté des Lettres et Sciences Humaines Département de Géographie (UCAD), Mémoire Aménagement du Territoire, Décentralisation et Développement Local (Atddl).

[30] Birkmann, J., Cardona, O.D., Carreño, M.L., Barbat, A.H., Pelling, M., Schneiderbauer, S., Kienberger, S., Keiler, M., Alexander, D., Zeil, P. and Welle, T. (2013) Framing Vulnerability, Risk and Societal Responses: The MOVE Framework. Natural Hazards, 67, 193-211. http://dx.doi.org/10.1007/s11069-013-0558-5

[31] Ferrand, A. (1996) Capital social comme échange social. Colloque: Trente ans de sociologie, Institut de Sociologie de Lille, Lille.

[32] Ojigi, M.L., Abdulkadir, F.I. and Aderoju, M.O. (2013) Geospatial Mapping and Analysis of the 2012 Flood Disaster in Central Parts of Nigeria. 8th National GIS Symposium, Dammam, 15-17 April 2013, 1-14.

[33] O’Brien, K. and Barnett, J. (2013) Global Environmental Change and Human Security. Annual Review of Environment and Resources, 38, 373-391. http://dx.doi.org/10.1146/annurev-environ-032112-100655 


\section{Submit or recommend next manuscript to SCIRP and we will provide best service for you:}

Accepting pre-submission inquiries through Email, Facebook, LinkedIn, Twitter, etc.

A wide selection of journals (inclusive of 9 subjects, more than 200 journals)

Providing 24-hour high-quality service

User-friendly online submission system

Fair and swift peer-review system

Efficient typesetting and proofreading procedure

Display of the result of downloads and visits, as well as the number of cited articles

Maximum dissemination of your research work

Submit your manuscript at: http://papersubmission.scirp.org/ 